\title{
Article \\ Psychological Variables Associated with HPV Vaccination Intent in Romanian Academic Settings
}

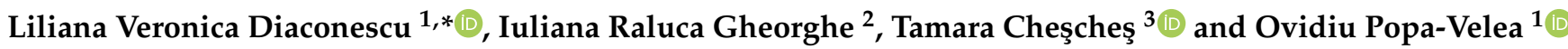 \\ 1 Department of Medical Psychology, Faculty of Medicine, University of Medicine and Pharmacy \\ “Carol Davila", 050474 Bucharest, Romania; ovidiu.popa-velea@umfcd.ro \\ 2 Department of Marketing and Medical Technology, Faculty of Medicine, University of Medicine and \\ Pharmacy "Carol Davila", 050474 Bucharest, Romania; raluca.gheorghe@umfcd.ro \\ 3 “Sf. Ioan" Emergency Clinical Hospital, 042122 Bucharest, Romania; tamara.chesches@rez.umfcd.ro \\ * Correspondence: liliana.diaconescu@umfcd.ro
}

check for

updates

Citation: Diaconescu, L.V.; Gheorghe, I.R.; Cheşcheş, T.; Popa-Velea, O. Psychological Variables Associated with HPV Vaccination Intent in Romanian Academic Settings. Int. J. Environ. Res. Public Health 2021, 18, 8938. https:// doi.org/10.3390/ijerph18178938

Academic Editor:

Italo Francesco Angelillo

Received: 13 July 2021

Accepted: 20 August 2021

Published: 25 August 2021

Publisher's Note: MDPI stays neutral with regard to jurisdictional claims in published maps and institutional affiliations.

Copyright: (c) 2021 by the authors. Licensee MDPI, Basel, Switzerland. This article is an open access article distributed under the terms and conditions of the Creative Commons Attribution (CC BY) license (https:// creativecommons.org/licenses/by/ $4.0 /)$.

\begin{abstract}
The aim of this study was to evaluate (1) the female medical students' knowledge about HPV infection; (2) the associations between the HPV vaccination intent and coping strategies, health locus of control (HLOC), and sense of coherence; and (3) the specific differences between preclinical and clinical students in terms of the vaccination intent. Participants included 1243 female medicine students (mean age $=21.526, \mathrm{SD}=2.007$ ), who completed The Multidimensional Health Locus of Control (MHLC) - Form A, the Brief COPE Scale, the Sense of Coherence Scale (SOC-13), and two questionnaires measuring the knowledge about the HPV infection and the HPV vaccination intent. Results show a good knowledge about HPV, which progressively increased during the study cycles. Still, the main contributors to vaccination intent are represented by coping strategies and health locus of control. Refusal of vaccination is associated to behavioral disengagement and the use of religion, precontemplation and contemplation to denial, and preparation to planning, positive reframing, and the powerful others component of HLOC. Sense of coherence did not predict vaccination intent. In clinical years, active coping outweighs HLOC in making the decision to get vaccinated. These results could be helpful in designing personalized strategies for addressing vaccine hesitancy in academic communities.
\end{abstract}

Keywords: vaccination intent; HPV; coping; sense of coherence; health locus of control; academic

\section{Introduction}

Human papillomavirus (HPV) is the most commonly sexually transmitted infection (STI) in the world [1] and has the highest prevalence among females aged 20 to 24 years [2]. In terms of mortality, HPV represents the most frequent cause of cervical cancer, especially in less developed countries [3-5].

The administration of the HPV vaccine has been reported to decrease the incidence of $\mathrm{HPV}$ infections and cervical cancer in general population [6-8]. Although the decision to get vaccinated can be dependent on the parental consent in adolescence $[9,10]$, it becomes a matter of self-decision in adult women [11]. Despite this, only $12 \%$ of females and $3 \%$ of males reported initiating the HPV vaccine in adulthood [12]. A series of factors are worldwide known to account for this phenomenon, such as the lack of awareness about HPV infection [13], the fear of needles and of side effects [11,14,15], mistrust in the HPV vaccine [16-18], perceived low risk of contracting HPV and its perceived low severity [15], decreased health care utilization by young people [19], economic disadvantage and low financial income [11], and negative social influence from peers and social media $[18,20-24]$.

In Romania, the age-standardized incidence of cervical cancer is 20 new cases $/ 100,000$ women [25], with the highest cervical cancer mortality (14.2 deaths/100,000 women) among the EU countries [26]. Although many Romanian women are aware of the existence of this disease and of the testing process, their knowledge is generally superficial (e.g., 
94.5\% heard of Pap smear, but only 58.7\% know what it actually is) [27]. This attitude is mirrored with the HPV vaccine. A first initiative of HPV vaccination was launched in Romania in 2008, when a free-of-charge vaccination program, coordinated by the Ministry of Health, was organized for all girls aged 10-11. The success rate of the program was, however, very low, with only $2.57 \%$ of the eligible girls getting immunized [28]. In 2009, before the campaign was resumed, the Ministry of Health included a preliminary phase of communication about HPV-associated risks and HPV vaccination, but the vaccine coverage remained low (9\%) [29]. In January 2020, after an 11-year break, the program was continued, preceded by an information and public awareness campaign about the dangers related to the HPV and the protection offered by the vaccine. This time, the program included an additional support section for physicians and pharmacists in order to help them provide clear and accurate information about HPV vaccination to interested individuals. The vaccination itself was offered to girls aged 11-14 years old whose parents previously requested vaccination $[30,31]$. The evaluation of this new initiative is still under way, but preliminary assessment indicates a lower rate of vaccination than expected and the need for more active information and preventive measures to accelerate its acceptance. Many subjective reasons could have led to vaccination reluctance, including the overall risky perception of the vaccine, the fear of adverse effects, the novelty of its implementation, the beliefs of associated infertility risks, and the perception of the vaccination procedure as an experiment [32,33]. Globally, in the Romanian population, decisions about HPV vaccination seem mostly influenced by negative emotions (possibly generated by the insufficient information provided by the health system and by a negative campaign carried out by mass media $[32,34]$ ), which far outweigh the gaps in knowledge about HPV infection and HPV vaccine [35]. Vulnerable women are exposed to an even higher risk of contracting HPV and may feel embarrassed to freely disclose their frail medical and psychological status [36,37].

While exploring the psychological factors associated with vaccination opposition and vaccine hesitancy, a series of variables appear to be important:

- Health locus of control (HLOC): low levels of internal HLOC may lead to decreased compliance to vaccinations [38]. In contrast, higher values are associated not only to pro-vaccination attitudes but also to preventive behaviors and higher adherence [39];

- Coping strategies: avoidance-focused coping is reported in literature to have a negative impact on the vaccination intent, while more active, problem-focused strategies are related to preventive behavior and a higher propensity to seek vaccination [40,41]; - $\quad$ Sense of coherence (SOC): has a moderating and a mediating effect on health [42]. People with a low SOC tend to be in poorer health $[43,44]$ and rarely display preventive behaviors, such as vaccination; and

- Stages of change: people in the precontemplation stage have no intention to change their behavior [45] and thereby are vaccine hesitant. However, individuals in this group as well as those in the contemplation phase could be subjects of targeted interventions to increase vaccine acceptance.

Beside the aforementioned variables, a considerable barrier in vaccination campaigns is represented by the lack of awareness and knowledge about HPV infection and vaccination $[35,46]$. As revealed in various studies, in many cases, the knowledge is assessed as poor or inaccurate [47,48]. Inversely, high levels of knowledge along with perceived severity are associated with the increased inclination to get vaccinated $[49,50]$.

In the academic communities, in particularly in medical universities, not many female students talk freely about the health risks associated with their sexual behavior or about their HPV vaccine hesitancy [51] even in self-help therapeutic groups [52,53]. Nevertheless, the investigation into vaccine perception in this population is important for at least three reasons: (a) their averagely higher levels of education allow for a much more sensitive evaluation of the role of psychological variables in their pro- or anti-vaccination intent; (b) these students could represent credible sources of medical information, thereby influencing the choice of other individuals around them to get vaccinated; and (c) they pertain to an age group where the catch-up vaccination is feasible. 
The aim of this study was (1) to evaluate the female medical students' knowledge about HPV infection; (2) to assess the specific differences and the comparative predictive value of coping strategies, health locus of control (HLOC), and sense of coherence in regards to the HPV vaccination intent; and (3) to evaluate the specific differences between vaccination intent in students having an exclusive theoretical knowledge of HPV and those students with clinical experience with HPV infection and consequences, i.e., cervical cancer.

\section{Materials and Methods}

\subsection{Design}

The design of the study was cross-sectional, with a single administration of a series of standardized psychometric instruments.

\subsection{Participants}

In order to ensure representativity of the study sample, we included in the study 1243 medical students (mean age $=21.526, \mathrm{SD}=2.007$ ) from 9 medical universities in three different regions of Romania and Bucharest. We recruited a convenience sample of medical students through posted announcements on their institutional online groups. This process was based on the participants' availability until the time limit was reached. All participants met the inclusion criteria, set as (1) being female, at least 19 years of age, and having the status of current undergraduate students in the abovementioned institutions and (2) having offered the informed consent to participate in the study. Exclusion criteria were represented by (1) students already vaccinated with one or more doses of the HPV vaccine, (2) students displaying current self-reported somatic or psychiatric morbidity, (3) students with cognitive deficits or any other impairments that would render the understanding and completion of the study questionnaires difficult, and (4) lack of completion of one or more study instruments.

\subsection{Procedure}

Data were collected in May-November 2020 through the administering of an online set of questions containing the study instruments. Before taking part in this research, students who expressed interest in participating received an explanatory statement about the study and completed informed consent forms. Subsequently, they were sent the web link for answering the psychometric instruments and the survey. Procedures in the study were designed in accordance with the World Medical Association Declaration of Helsinki and with the ethical guidelines published by the Committee of Ethics at the University of Medicine and Pharmacy Carol Davila-Bucharest (ethical approval no. 10098/13 May 2020). A researcher (TC) was available by phone or email in case the participants had questions concerning the filling of the questionnaires. All responses were processed anonymously, and a numerical code was assigned for each participant. The collected data were accessible exclusively to study researchers (OPV, IRG, TC, LVD), while regular didactic staff had no access to the nominal distribution, collection, or interpretation of questionnaires. The interpretation of the questionnaires was performed independently by two researchers (IRG, TC) and cross-checked for congruence afterwards. Final results were included in a SPSS 21 (SPSS ${ }^{\circledR}$ Inc., Chicago, IL, USA) database.

\subsection{Instruments}

1. The Multidimensional Health Locus of Control (MHLC)—Form A [54] comprises 18 items in three subscales ("internality", "powerful others externality", and "chance externality"), allowing the identification of the predominant source of identified control over one's health. The answers are given on a 6-point Likert scale (ranging from $1=$ "strongly disagree" to $6=$ "strongly agree"). The MHLC is used to predict health behaviors, including preventive attitudes, and was reported to display a good reliability $(0.69-0.72)[55,56]$. 
2. Brief COPE Scale contains 28 items, which measure 14 distinct coping strategies [57]. The answers are graded on a 4-point Likert scale (from $1=$ "I haven't been doing this at all" to $4=$ "I have been doing this a lot"). The test has generally been reported to have good reliability $(0.50-0.90)[57,58]$ and is validated in the Romanian population.

3. The Sense of Coherence Scale- the shorter version with 13 questions (SOC-13) [59] measures how a person handles stress, by referring to the Antonovsky's definition of SOC [60], consisting of three components: comprehensibility, manageability, and meaningfulness. Comprehensibility deals with the extent to which a person sees the world as ordered and is able to mobilize the resources needed to cope. Manageability refers to understanding the problem and having the necessary resources to cope successfully. Meaningfulness pertains to the belief that coping makes sense and that one wishes to cope. The responses on the scale are placed on a semantic scale of 1 point to 7 points, where 1 and 7 indicate extreme feelings about questions (and statements) about how one's life is experienced. The total score ranges between 13 and 91 points. The scale has a good Cronbach alpha coefficient of 0.74-0.91 [61].

4. The questionnaire of knowledge about HPV infection, extracted from previous published research on this theme [61], contains 16 items, to which the answers are binary ("true" or "false"). The instrument has a very good internal consistency (Cronbach alpha $=0.849)$ [62].

5. The questionnaire about the HPV vaccination intent, adapted from an instrument used previously [63] and constructed according to the description of stages in the Transtheoretical Model of Change (TTM) [64], includes 10 items, relevant for:

- The refusal of vaccination (e.g., "I do not plan to get vaccinated ever against HPV");

- Precontemplation (e.g., "Although vaccination is a good thing, I am unsure about my intention to get vaccinated");

- Contemplation (e.g., "I am willing to get vaccinated, but I do not plan this in the next 6 months");

- Preparation (e.g., "I plan to get vaccinated (first shot) in the next 6 months, but I have not tried yet to schedule an appointment");

- Action (e.g., "I have already scheduled an appointment, and I have received at least one shot of the HPV vaccine").

The questionnaire was reported to display a good content validity [65].

\subsection{Data Analysis}

Descriptive analyses were realized for socio-demographic and psychological variables.

Statistical analysis was performed with SPSS Statistics 21 (SPSS ${ }^{\circledR}$ Inc., Chicago, IL, USA). It comprised one-way ANOVA (followed by Tukey's post-hoc tests) to compare the differences among study groups and multiple logistic regression to identify the predictors of the vaccination intent for each distinct phase of the TTM model. Additionally, separate $t$-tests for independent samples to compare the results of students in the sixth study year (who have been exposed to both theory and practice regarding HPV and its consequences) to those in the second study year (who have an exclusively theoretical understanding of HPV).

Throughout statistical analyses, missing data were handled through listwise deletion. For all calculations, the threshold of statistical significance was $p<0.05$.

\section{Results}

\subsection{Descriptive Data}

The study sample was subdivided into three distinct categories according to their responses at the questionnaire about the HPV intent (Table 1):

- Group 1: no vaccination intent: $n=196$ (15.8\%);

- Group 2: the vaccination intent is only theoretical and consists in thoughts about the utility of the vaccine (precontemplation: $n=175(n=14.1 \%)$ ) or about the personal benefit from getting vaccinated (contemplation: $n=546(43.9 \%)$ ); and 
- Group 3: the vaccination intent is not only theoretical, but it has also a practical component (preparation: $n=326(26.2 \%)$ ).

Table 1. Biographic variables.

\begin{tabular}{|c|c|c|c|c|c|c|c|c|c|}
\hline \multirow{2}{*}{\multicolumn{2}{|c|}{$\begin{array}{c}\text { Variables } \\
\text { A. Scale variables }\end{array}$}} & \multicolumn{2}{|c|}{$\begin{array}{l}\text { Whole Sample } \\
\qquad(N=1243)\end{array}$} & \multicolumn{2}{|c|}{$\begin{array}{l}\text { Group 1* } \\
(N=196)\end{array}$} & \multicolumn{2}{|c|}{$\begin{array}{l}\text { Group } 2 * * \\
(N=721)\end{array}$} & \multicolumn{2}{|c|}{$\begin{array}{c}\text { Group } 3 * * * \\
(N=326)\end{array}$} \\
\hline & & Mean & SD & Mean & SD & Mean & SD & Mean & SD \\
\hline & & 21.526 & 2.007 & 21.571 & 1.897 & 21.514 & 2.130 & 21.527 & 1.783 \\
\hline B. Nomin & ariables & $N$ & $\%$ & $N$ & $\%$ & $N$ & $\%$ & $N$ & $\%$ \\
\hline \multirow{2}{*}{ Origin } & urban & 982 & 79.001 & 148 & 75.510 & 570 & 79.056 & 264 & 80.981 \\
\hline & rural & 261 & 20.998 & 48 & 24.490 & 151 & 20.944 & 62 & 19.019 \\
\hline \multirow{6}{*}{$\begin{array}{l}\text { Year of } \\
\text { study }\end{array}$} & 1 & 174 & 13.998 & 35 & 17.857 & 101 & 14.008 & 38 & 11.656 \\
\hline & 2 & 275 & 22.124 & 36 & 18.367 & 165 & 22.885 & 74 & 22.699 \\
\hline & 3 & 268 & 21.561 & 35 & 17.857 & 162 & 22.469 & 71 & 21.780 \\
\hline & 4 & 192 & 15.446 & 31 & 15.817 & 110 & 15.257 & 51 & 15.644 \\
\hline & 5 & 164 & 13.194 & 23 & 11.735 & 91 & 12.621 & 50 & 15.337 \\
\hline & 6 & 170 & 13.677 & 36 & 18.367 & 92 & 12.760 & 42 & 12.884 \\
\hline \multirow{4}{*}{$\begin{array}{l}\text { Country } \\
\text { region }\end{array}$} & Bucharest & 149 & 11.987 & 26 & 13.265 & 71 & 9.848 & 52 & 15.952 \\
\hline & South & 276 & 22.205 & 42 & 21.428 & 163 & 22.607 & 71 & 21.779 \\
\hline & Northwest & 679 & 54.625 & 103 & 52.552 & 407 & 56.449 & 169 & 51.840 \\
\hline & Northeast & 139 & 11.183 & 25 & 12.755 & 80 & 11.096 & 34 & 10.429 \\
\hline
\end{tabular}

${ }^{*}$ Group 1 = no intent of vaccination; ${ }^{* *}$ Group 2 = precontemplation and contemplation; ${ }^{* * *}$ Group $3=$ preparation. $\mathrm{SD}=$ standard deviation.

The vast majority of the respondents (79.001\%) originated in urban areas. A majority of them studied in the Northwest regions of the country $(54.625 \%)$. Most of the participants were enrolled in the clinical study years (3-6) $(63.878 \%)$.

Table 2 synthesizes the results obtained by the three study groups at the tests assessing HPV knowledge and psychological variables (coping strategies, health locus of control, and sense of coherence).

Table 2. HPV knowledge and psychological variables.

\begin{tabular}{|c|c|c|c|c|c|c|c|c|c|}
\hline & \multirow{2}{*}{ Variables } & \multicolumn{2}{|c|}{$\begin{array}{l}\text { Whole Sample } \\
\quad(N=1243)\end{array}$} & \multicolumn{2}{|c|}{$\begin{array}{l}\text { Group } 1 * \\
(N=196)\end{array}$} & \multicolumn{2}{|c|}{$\begin{array}{l}\text { Group } 2 * * \\
(N=721)\end{array}$} & \multicolumn{2}{|c|}{$\begin{array}{c}\text { Group } 3 * * * \\
(N=326)\end{array}$} \\
\hline & & Mean & SD & Mean & SD & Mean & SD & Mean & SD \\
\hline \multirow{14}{*}{$\begin{array}{l}\text { Coping } \\
\text { strategies }\end{array}$} & Self-distraction & 5.576 & 1.476 & 5.637 & 1.480 & 5.535 & 1.471 & 5.628 & 1.486 \\
\hline & Active coping & 6.759 & 1.152 & 6.719 & 1.202 & 6.718 & 1.156 & 6.874 & 1.109 \\
\hline & Denial & 3.571 & 1.500 & 3.571 & 1.536 & 3.663 & 1.528 & 3.368 & 1.397 \\
\hline & Substance use & 2.683 & 1.356 & 2.658 & 1.309 & 2.683 & 1.373 & 2.696 & 1.351 \\
\hline & Use of emotional support & 5.353 & 1.696 & 5.505 & 1.672 & 5.341 & 1.654 & 5.288 & 1.798 \\
\hline & Use of instrumental support & 5.844 & 1.615 & 5.811 & 1.614 & 5.876 & 1.606 & 5.794 & 1.639 \\
\hline & Behavioral disengagement & 2.884 & 1.170 & 3.097 & 1.247 & 2.883 & 1.176 & 2.757 & 1.090 \\
\hline & Venting & 5.298 & 1.646 & 5.530 & 1.702 & 5.227 & 1.615 & 5.316 & 1.672 \\
\hline & Positive reframing & 5.846 & 1.472 & 5.586 & 1.552 & 5.834 & 1.473 & 6.027 & 1.400 \\
\hline & Planning & 6.787 & 1.134 & 6.770 & 1.161 & 6.760 & 1.119 & 6.858 & 1.150 \\
\hline & Humor & 5.546 & 1.856 & 5.352 & 1.821 & 5.533 & 1.869 & 5.690 & 1.843 \\
\hline & Acceptance & 6.148 & 1.318 & 6.046 & 1.345 & 6.091 & 1.312 & 6.334 & 1.299 \\
\hline & Religion & 4.546 & 1.968 & 4.903 & 2.126 & 4.474 & 1.966 & 4.490 & 1.853 \\
\hline & Self-blame & 5.478 & 1.612 & 5.515 & 1.650 & 5.470 & 1.626 & 5.475 & 1.562 \\
\hline
\end{tabular}


Table 2. Cont.

\begin{tabular}{|c|c|c|c|c|c|c|c|c|c|}
\hline & \multirow{2}{*}{ Variables } & \multicolumn{2}{|c|}{$\begin{array}{l}\text { Whole Sample } \\
\qquad(N=1243)\end{array}$} & \multicolumn{2}{|c|}{$\begin{array}{l}\text { Group } 1 * \\
(N=196)\end{array}$} & \multicolumn{2}{|c|}{$\begin{array}{c}\text { Group } 2 * * \\
(N=721)\end{array}$} & \multicolumn{2}{|c|}{$\begin{array}{l}\text { Group } 3 * * * \\
(N=326)\end{array}$} \\
\hline & & Mean & SD & Mean & SD & Mean & SD & Mean & SD \\
\hline \multicolumn{2}{|c|}{ HPV knowledge } & 12.245 & 1.872 & 12.214 & 1.810 & 12.242 & 1.895 & 12.269 & 1.860 \\
\hline \multirow{3}{*}{$\begin{array}{l}\text { Health } \\
\text { locus of } \\
\text { control }\end{array}$} & Internal & 25.823 & 4.723 & 25.663 & 4.868 & 25.771 & 4.778 & 26.036 & 4.516 \\
\hline & External (chance) & 15.985 & 5.115 & 16.403 & 5.382 & 15.833 & 5.001 & 16.070 & 5.199 \\
\hline & $\begin{array}{l}\text { External } \\
\text { (powerful others) }\end{array}$ & 23.385 & 5.274 & 21.928 & 5.452 & 23.299 & 5.281 & 24.450 & 4.922 \\
\hline \multicolumn{2}{|c|}{ Sense of coherence } & 49.134 & 9.739 & 48.270 & 8.937 & 49.233 & 9.799 & 49.435 & 10.064 \\
\hline
\end{tabular}

${ }^{*}$ Group 1 = no intent of vaccination; ${ }^{* *}$ Group 2 = precontemplation and contemplation; ${ }^{* *}$ Group $3=$ preparation. SD $=$ standard deviation. HPV, Human Papilloma Virus.

Across the whole sample, the most preferred coping strategies were planning, active coping, and acceptance, while the least preferred were substance use and behavioral disengagement. Several differences emerged between groups, with a more substantial use of behavioral disengagement and religion in group 1, denial and seek for instrumental support in group 2, and planning and positive reframing in group 3.

The HPV knowledge was satisfactory in all study groups and the whole sample (range 12.214-12.269 out of 16).

The sense of coherence had a high dispersion of results (range 23-83), with the sample mean (49.134) placed among the low scores reported in literature for academic populations [66-68].

In terms of health locus of control, most students placed its main source internally, followed by the powerful others and by chance. This hierarchy was maintained irrespective of the participants' vaccination intent.

\subsection{Statistical Differences between Groups}

Table 3 displays the significant differences between the three study groups (ANOVA) and the sources of these differences (Tukey's post-hoc tests).

Students refusing vaccination (group 1) had significantly higher scores in behavioral disengagement and lower scores in positive reinterpretation compared to students preparing for getting vaccinated (group 3). Moreover, they had a significantly higher use of religion compared to students only thinking about vaccination (group 2).

Students in group 3 had significantly lower scores of denial and marginally higher scores of acceptance compared to those in group 2.

All the three groups differed significantly in terms of the role played by the powerful others, this getting progressively more important from group 1 to group 3 . 
Table 3. Statistical differences between the study groups *.

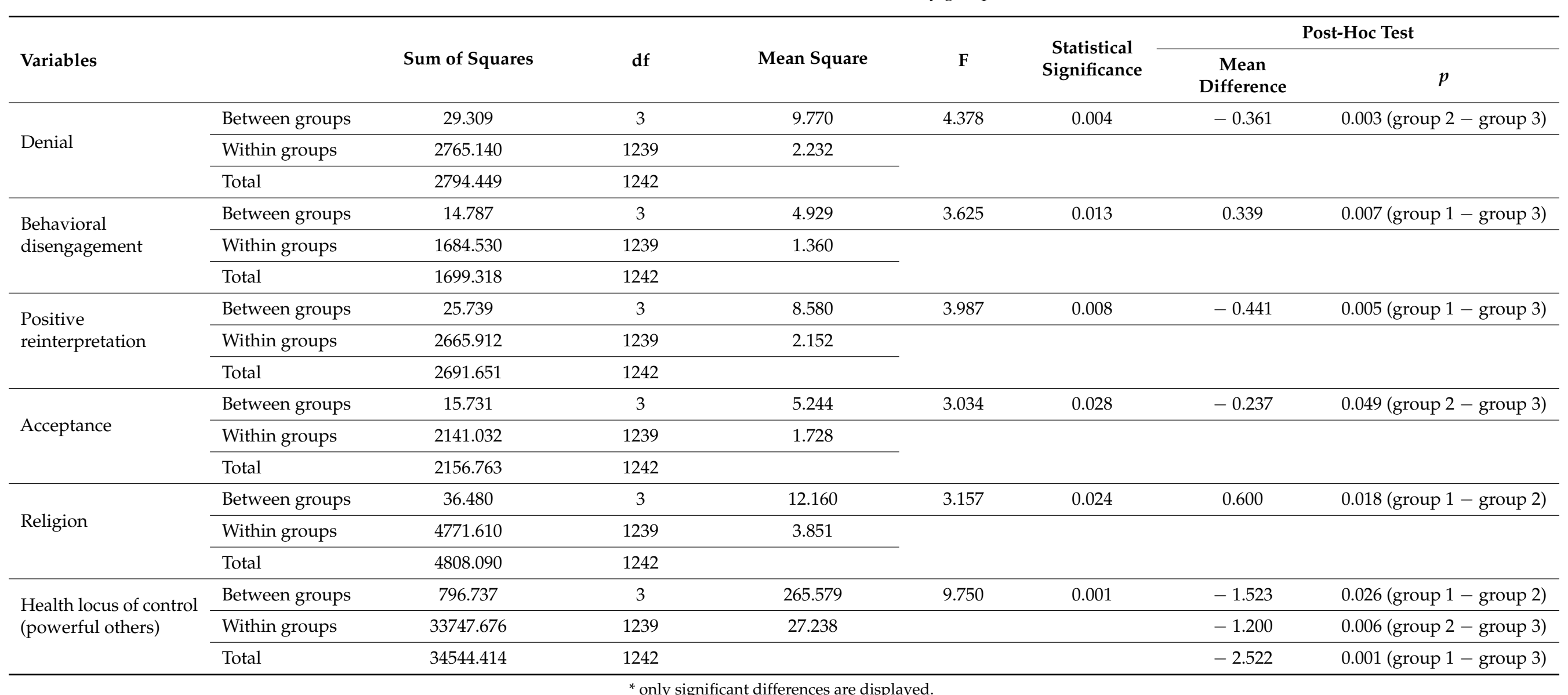

* only significant differences are displayed. 


\subsection{Predictors of the Vaccination Intent}

Multinominal regression analysis was used to identify the predictors of the vaccination intent. Results are displayed in Table 4.

Table 4. Predictors of the vaccination intent

\begin{tabular}{|c|c|c|c|c|c|}
\hline & \multirow[b]{2}{*}{ Effect } & \multirow{2}{*}{$\begin{array}{c}\text { Model Fitting Criteria } \\
-2 \text { Log Likelihood of } \\
\text { Reduced Model }\end{array}$} & \multicolumn{3}{|c|}{ Likelihood Ratio Tests } \\
\hline & & & Chi-Square & df & $\begin{array}{c}\text { Statistical } \\
\text { Significance }\end{array}$ \\
\hline & Intercept & $3054.108^{a}$ & 0.000 & 0 & . \\
\hline & IPV knowledge & 3054.528 & 0.420 & 3 & 0.936 \\
\hline \multirow{14}{*}{ Coping } & Self-distraction & 3055.586 & 1.479 & 3 & 0.687 \\
\hline & Active coping & 3055.602 & 10.495 & 3 & 0.684 \\
\hline & Denial & 3066.441 & 120.333 & 3 & 0.006 \\
\hline & Substance use & 3059.637 & 50.529 & 3 & 0.137 \\
\hline & Use of emotional support & 3057.981 & 30.873 & 3 & 0.275 \\
\hline & Use of instrumental support & 3060.264 & 60.156 & 3 & 0.104 \\
\hline & Behavioral disengagement & 3061.223 & 70.115 & 3 & 0.068 \\
\hline & Venting & 3059.461 & 50.353 & 3 & 0.148 \\
\hline & Positive reframing & 3065.513 & 110.405 & 3 & 0.010 \\
\hline & Planning & 3057.736 & 30.628 & 3 & 0.305 \\
\hline & Humor & 3054.381 & 0.273 & 3 & 0.965 \\
\hline & Acceptance & 3056.343 & 20.235 & 3 & 0.525 \\
\hline & Religion & 3064.931 & 100.823 & 3 & 0.013 \\
\hline & Self-blame & 3056.918 & 20.810 & 3 & 0.422 \\
\hline \multicolumn{2}{|c|}{ Sense of coherence } & 3054.514 & 0.406 & 3 & 0.939 \\
\hline \multirow{3}{*}{$\begin{array}{l}\text { Health locus of } \\
\text { control }\end{array}$} & Internal & 3057.508 & 30.400 & 3 & 0.334 \\
\hline & Chance & 3057.068 & 20.960 & 3 & 0.398 \\
\hline & Powerful others & 3087.104 & 320.996 & 3 & 0.001 \\
\hline & Year of study & 3071.016 & 160.908 & 15 & 0.324 \\
\hline
\end{tabular}

${ }^{a}$ The reduced model was equivalent to the final model because omitting the effect did not increase the degrees of freedom.

The goodness-of-fit of the model was satisfactory (chi-square $=164.710, \mathrm{df}=158, p<0.341$ ).

Across the whole TTM stages, the most important predictors were denial $(p<0.003)$, positive reframing $(p<0.010)$, religion $(p<0.013)$, and health locus of control (the powerful others component) $(p<0.001)$.

Participants in group 1 were characterized, compared to group 3, by higher scores in behavioral disengagement $(\mathrm{B}=0.234$, standard error $=0.089, \mathrm{df}=1, p<0.008)$ and religion $(\mathrm{B}=0.129$, standard error $=0.050, \mathrm{df}=1, p<0.010)$ and lower scores in positive reframing $(B=-0.258$, standard error $=0.078, \mathrm{df}=1, p<0.001)$. In addition, those in group 1 counted less on powerful others $(\mathrm{B}=-0.112$, standard error $=0.020, \mathrm{df}=1, p<0.001)$.

Similarly, participants in group 2 were characterized, compared to group 3 , by lower scores on the powerful others component of the HLOC scale $(B=-0.050$, standard error $=0.020, \mathrm{df}=1, p<0.014$ ).

\subsection{Preclinical-Clinical Differences}

These differences were evaluated by comparing students in the preclinical cycle (in the second study year, having an exclusively theoretical knowledge of HPV) and students in the 
clinical cycle (sixth year, with clinical experience with HPV infection and its consequences).

The significant results of this analysis are displayed in Table 5.

Table 5. Preclinical-clinical differences ${ }^{a}$.

\begin{tabular}{|c|c|c|c|c|c|c|c|}
\hline \multirow{2}{*}{ Variables } & \multicolumn{2}{|c|}{ 2nd-Year Students } & \multicolumn{2}{|c|}{ 6th-Year Students } & \multirow[t]{2}{*}{$\mathbf{t}$} & \multirow[t]{2}{*}{ df } & \multirow[t]{2}{*}{$p$} \\
\hline & Mean & SD & Mean & SD & & & \\
\hline \multicolumn{8}{|l|}{ A. Group $1^{*}$} \\
\hline HPV knowledge & 11.611 & 1.809 & 12.972 & 1.576 & -3.403 & 70 & 0.001 \\
\hline \multicolumn{8}{|l|}{ B. Group $2^{* *}$} \\
\hline HPV knowledge & 11.957 & 1.842 & 12.891 & 1.607 & -4.073 & 255 & 0.0005 \\
\hline \multicolumn{8}{|l|}{ C. Group $3^{* * *}$} \\
\hline HPV knowledge & 11.581 & 1.79 & 12.809 & 1.627 & -3.669 & 114 & 0.0005 \\
\hline Active coping & 6.878 & 1.02 & 7.285 & 0.918 & -2.142 & 114 & 0.034 \\
\hline HLOC (powerful others) & 24.972 & 4.385 & 22.761 & 4.471 & 2.591 & 114 & 0.011 \\
\hline
\end{tabular}

As expected, students in the sixth study year, irrespective of their vaccination intent, had statistically more HPV knowledge than those in the second year.

Still, the students in the preparation phase had two additional particularities: they tended to follow, in terms of health, an authoritative figure (if they were in the preclinical cycle) or were significantly more active (if they were in the clinical cycle).

\section{Discussion}

This study focused on assessing the female medical students' knowledge about HPV infection; the specific differences and the comparative predictive value of coping strategies, health locus of control (HLOC), and sense of coherence in regards to the HPV vaccination intent; and the specific differences between vaccination intent in students in the preclinical and clinical study cycles after having been exposed to HPV and its consequences.

The descriptive data illustrated a satisfactory overall level of knowledge about HPV (12.25 out of 16). This finding was to a certain point predictable given that medical students are in direct and frequent contact with health information about HPV and associated risk factors.

The most used coping strategies were generally the adaptive ones (planning, active coping, acceptance, and positive reframing), while the least used were the avoidant ones (denial, behavioral disengagement, substance use). Generally, the use of this kind of strategies is associated, in medical students, with better health outcomes [69]. In the particular case of our study, this may reflect the intention of the participants as a whole to be actively involved in aspects related to their health, including preventive behaviors. From a prognostic perspective, this could be associated in the long term with a lower risk of cervical cancer and/or with a better management of this disease.

Still, significant differences were met between the three study groups in terms of coping strategies preferences. Participants who did not express the intention to get the $\mathrm{HPV}$ vaccine (group 1) were characterized by behavioral disengagement and the use of religion, reflecting a higher orientation towards emotion-focused coping in handling difficult, uncertain, or risky circumstances. In contrast, the respondents in the precontemplation and contemplation stages (group 2) used more often denial. In terms of long-term evolution, this could be potentially dangerous, as they may lack awareness about the risk to get the $\mathrm{HPV}$ infection and/or cervical cancer and may stagnate in these stages for a long time or even return to the previous one (no vaccination intent). Still, the regular use of instrumental support by these participants could offer reasons of hope, as this could be associated with 
a higher tendency to ask for help and support if needed. Individuals belonging to the preparation stage (group 3) preferred planning and positive reframing as tools to better handle stressful emotions (such as those related to the risk of HPV infection or to fear of the vaccine's side effects). These could have helped them to see the HPV-associated risks in more positive and resolvable terms.

In terms of the sense of coherence, this was assessed as lower than normal in all three study groups. Furthermore, the sense of coherence did not prove in our study to be predictive for the vaccination intent; in other words, understanding the link between vaccination and the lower risk of cervical cancer could have not played a significant role in adopting this preventive behavior. These findings come in contrast with other literature studies that illustrate the importance of the sense of coherence for developing the intention to get vaccinated [70]. This contradiction could stem from the large dispersion of the SOC results (possibly reflecting a lack of proper understanding of the test questions) but could be equally explained by the already vaccinated individuals (possibly with a higher SOC) not having taken part in the study. Another possibility for a lower SOC could stem from its general tendency to decrease during the SARS-CoV-2 pandemic, especially in women, on the general background of higher insecurity and contradictory information surrounding COVID-19 [71,72].

Regarding the health locus of control, most of the students had a high level of internal HLC, followed by the powerful others HLC and chance HLC. This evidence is encouraging, as the predominance of the internal HLC could reflect the will and the ability to perform preventive behaviors, such as vaccination. Literature data using standardized instruments also confirm that high internal HLC correlates positively with preventive behaviors [73-76] and in particular with adherence to the cervical cancer screening programs [77], getting even stronger after vaccination [78]. Oppositely, fatalistic beliefs and/or lack of control are associated with a low adherence to HPV vaccination [79].

In what concerned the contribution brought by the powerful others HLC, this could have played in the studied group an additional role in the decision to actually perform HPV vaccination. This effect, in relation to the specific authority brought by the physicians' expertise, has been also reported in literature [80]. However, it should be emphasized that this effect is not guaranteed in the long run, as the position of the influential sources regarding vaccination could vary in time or according to circumstances. Similarly, the chance HLC can also represent a factor potentially leading to vaccine hesitancy or denial.

In terms of the predictors of the vaccination intent, the students in group 1 differed from those in group 3 essentially through their higher scores in behavioral disengagement and religion. They seem also to be characterized by a certain psychological rigidity (as they display a low ability of positive reframing) and higher autonomy (as they lean less on powerful others in taking decisions about their health). In contrast, groups 2 and 3 differed essentially only in what concerned the higher importance of powerful others in the decision of getting vaccinated, met by the students from group 3. From this point of view, the personal example of the persons invested with authority (be this formal or informal) seems to be essential for making the transition from precontemplation/contemplation to preparation.

Although the level of knowledge about HPV was satisfactory, it did not represent, as such, a predictor of the vaccination intent. The high level of knowledge about HPV infection seems to be a necessary but not sufficient condition for determining the young, academic population to adopt a preventive HPV vaccine behavior. This result does not replicate the findings of previous studies on the same theme, which illustrate the positive predictive value of the level of HPV knowledge on vaccination intent $[81,82]$.

The specific comparisons realized between students in the preclinical cycle (second study year) and those in the clinical cycle (sixth study year) revealed that medical knowledge does not predict alone the active preparation for vaccination. Important additional elements are represented by the role of the powerful others (in the case of preclinical students) and active coping (in the case of clinical students). These characteristics could 
be very informative for the key players in the field of education in designing effective personalized programs in favor of vaccination.

\section{Limits of Research}

Our study has several limitations. Despite including students from all study years, it realized only a cross-evaluation of their vaccination intent. The study included only psychological variables and not social ones. Some variables, such as the powerful others HLOC, may have had an ambivalent influence in time on the vaccination intent. To further investigate the predictors of HPV vaccination, future research could include additional psychosocial factors relevant for personality or social conformity as well as social parameters reported in literature to influence the vaccination intent (e.g., income, access to vaccines, or the pervasive nature of restrictive group norms [83-85]).

\section{Conclusions}

This study offers evidence about the HPV knowledge and the factors influencing HPV vaccination intent among female medical students. Among these factors, the most important are HLOC (the powerful others component), coping strategies, and the position in the academic cycle.

Consequently, a series of practical aspects emerge as important for ensuring a higher chance of success of HPV vaccination programs in academic settings. This kind of programs should not rely only on information (especially as this is not by itself a predictor of the vaccination intent) but also on psychological variables (such as coping style, health locus of control, and the impact of significant others). They should be doable and flexible and always consider the placement of the individual in the stages-of-change continuum. For example, for vaccine skeptics and deniers, the most suitable strategies seem to be those focused on emotional coping in the sense of including positive cues for vaccination in their preferred ways of facing reality. For individuals in the precontemplation and contemplation phases, a particular importance should be given to the ambivalent use of denial and to their real (and not imaginary) ability to ask for and use instrumental support. In the case of those in the stage of preparation, they could be stimulated into action via strategies supporting planning, positive reframing, and external influencers.

Furthermore, the transition from preclinical to clinical teaching in medical universities should not only be considered as a simple change of the study curriculum but as an opportunity for many students to commute from a more external-oriented thinking style to more autonomy and goal-oriented behavior. This in turn could be reflected in the attitude towards medical interventions and should be addressed in programs supporting HPV vaccination.

As a whole, these findings can be useful in designing more effective strategies, whether they be health policies or informal actions from influencers or other opinion leaders, in order to increase HPV vaccine acceptance.

Author Contributions: Conceptualization, L.V.D. and O.P.-V.; methodology, O.P.-V., I.R.G. and L.V.D.; software: I.R.G.; validation, L.V.D. and O.P.-V.; formal analysis, I.R.G.; investigation, I.R.G., T.C.; resources, T.C.; data curation, I.R.G. and T.C.; writing-original draft preparation, O.P.-V.; writing-review and editing, L.V.D., I.R.G. and O.P.-V.; visualization, I.R.G.; supervision, L.V.D.; project administration, O.P.-V. and L.V.D.; funding acquisition, T.C. All authors have read and agreed to the published version of the manuscript.

Funding: This research received no external funding.

Institutional Review Board Statement: The study was conducted according to the guidelines of the Declaration of Helsinki and approved by the Ethics Committee of the University of Medicine and Pharmacy Carol Davila—Bucharest (no. 10098/13 May 2020).

Informed Consent Statement: Informed consent was obtained from all subjects involved in the study. 
Data Availability Statement: The dataset presented in this study is available on reasonable request from the corresponding author.

Acknowledgments: The authors would like to warmly thank to all the students participating in the study.

Conflicts of Interest: The authors declare no conflict of interest.

\section{References}

1. World Health Organization. Comprehensive Cervical Cancer Control: A Guide to Essential Practice, 2nd ed.; World Health Organization: Geneva, Switzerland, 2014; pp. 25-28.

2. Dunne, E.F.; Unger, E.R.; Sternberg, M.; McQuillan, G.; Swan, D.C.; Patel, S.S.; Markowitz, L.E. Prevalence of HPV infection among females in the United States. JAMA 2007, 297, 813-819. [CrossRef] [PubMed]

3. Bosch, F.X.; de Sanjosé, S. The epidemiology of human papillomavirus infection and cervical cancer. Dis. Mark. 2007, 23, 213-227. [CrossRef] [PubMed]

4. Bray, F.; Ferlay, J.; Soerjomataram, I.; Siegel, R.L.; Torre, L.A.; Jemal, A. Global cancer statistics 2018: GLOBOCAN estimates of incidence and mortality worldwide for 36 cancers in 185 countries. CA Cancer J. Clin. 2018, 68, 394-424. [CrossRef]

5. de Martel, C.; Plummer, M.; Vignat, J.; Franceschi, S. Worldwide burden of cancer attributable toHPV by site, country and HPV type. Int. J. Cancer 2017, 141, 664-670. [CrossRef]

6. Guo, F.; Hirth, J.M.; Berenson, A.B. Comparison of HPV prevalence between HPV-vaccinated and non-vaccinated young adult women (20-26 years). Hum. Vaccin. Immunother. 2015, 11, 2337-2344. [CrossRef]

7. Muñoz, N.; Kjaer, S.K.; Sigurdsson, K.; Iversen, O.E.; Hernandez-Avila, M.; Wheeler, C.M.; Perez, G.; Brown, D.R.; Koutsky, L.A.; Tay, E.H.; et al. Impact of human papillomavirus (HPV)-6/11/16/18 vaccine on all HPV-associated genital diseases in young women. J. Natl. Cancer Inst. 2010, 102, 325-339. [CrossRef] [PubMed]

8. Meites, E.; Szilagyi, P.G.; Chesson, H.W.; Unger, E.R.; Romero, J.R.; Markowitz, L.E. Human Papillomavirus vaccination for adults: Updated recommendations of the Advisory Committee on Immunization Practices. MMWR Morb. Mortal Wkly Rep. 2019, 68, 698-702. [CrossRef] [PubMed]

9. Constantine, N.A.; Jerman, P. Acceptance of human papillomavirus vaccine among Californian parents of daughters: A representative state wide analysis. J. Adolesc. Health 2007, 40, 108-115. [CrossRef]

10. De Visser, R.; McDonnell, E. Correlates of parents' reports of acceptability of human papillomavirus vaccine for their school-aged children. Sex. Health 2008, 5, 331-338. [CrossRef] [PubMed]

11. Teitelman, A.M.; Stringer, M.; Nguyen, G.T.; Hanlon, A.L.; Averbuch, T.; Stimpfel, A.W. Social cognitive and clinical factors associated with HPV vaccine initiation among urban, economically disadvantaged women. J. Obstet. Gynecol. Neonatal. Nurs. 2011, 40, 691-701. [CrossRef]

12. Williams, W.W.; Lu, P.J.; O’Halloran, A.; Kim, D.K.; Grohskopf, L.A.; Pilishvili, T.; Skoff, T.H.; Nelson, N.P.; Harpaz, R.; Markowitz, L.E.; et al. Surveillance of vaccination coverage among adult populations-United States, 2015. MMWR Surveill. Summ. 2017, 66, 1-28. [CrossRef]

13. Yacobi, E.; Tennant, C.; Ferrante, J.; Pal, N.; Roetzheim, R. University students' knowledge and awareness of HPV. Prev. Med. 1999, 28, 535-541. [CrossRef]

14. Hirth, J.M.; Batuuka, D.N.; Gross, T.T.; Cofie, L.; Berenson, A.B. Human papillomavirus vaccine motivators and barriers among community college students: Considerations for development of a successful vaccination program. Vaccine 2018, 36, 1032-1037. [CrossRef] [PubMed]

15. Yaqub, O.; Castle-Clarke, S.; Sevdalis, N.; Chataway, J. Attitudes to vaccination: A critical review. Soc. Sci. Med. 2014, 112, 1-11. [CrossRef] [PubMed]

16. DiAnna Kinder, F. Parental refusal of the human papillomavirus vaccine. J. Pediatr. Health Care 2016, 30, 551-557. [CrossRef] [PubMed]

17. Black, S.; Rappuoli, R. A crisis of public confidence in vaccines. Sci. Transl. Med. 2010, 2, 61mr1. [CrossRef] [PubMed]

18. Cvjetkovic, S.J.; Jeremic, V.L.; Tiosavljevic, D.V. Knowledge and attitudes toward vaccination: A survey of Serbian students. J. Infect. Public Health 2017, 10, 649-656. [CrossRef]

19. Rand, C.M.; Shone, L.P.; Albertin, C.; Auinger, P.; Klein, J.D.; Szilagyi, P.G. National health care visit patterns of adolescents: Implications for delivery of new adolescent vaccines. Arch. Pediatr. Adolesc. Med. 2007, 161, 252-259. [CrossRef]

20. Wang, L.D.-L.; Lam, W.W.T.; Wu, J.; Fielding, R. Psychosocial determinants of Chinese parental HPV vaccination intention for adolescent girls: Preventing cervical cancer. Psycho-Oncol. 2015, 24, 1233-1240. [CrossRef]

21. Zimmerman, R.K.; Wolfe, R.M.; Fox, D.E.; Fox, J.R.; Nowalk, M.P.; Troy, J.A.; Sharp, L.K. Vaccine criticism on the World Wide Web. J. Med. Internet Res. 2005, 7, e17. [CrossRef]

22. Keelan, J.; Pavri-Garcia, V.; Tomlinson, G.; Wilson, K. YouTube as a source of information on immunization: A content analysis. JAMA 2007, 298, 2482-2484. [CrossRef] [PubMed]

23. Kata, A. A postmodern Pandora's box: Anti-vaccination misinformation on the Internet. Vaccine 2010, 28, 1709-1716. [CrossRef]

24. Fernández-Luque, L.; Bau, T. Health and social media: Perfect storm of information. Healthc. Inform. Res. 2015, 21, 67-73. [CrossRef] [PubMed] 
25. Arbyn, M.; Antoine, J.; Mägi, M.; Smailyte, G.; Stengrevics, A.; Şuteu, O.; Valerianova, Z.; Bray, F.; Weiderpass, E. Trends in cervical cancer incidence and mortality in the Baltic countries, Bulgaria and Romania. Int. J. Cancer 2011, 128, 1899-1907. [CrossRef] [PubMed]

26. Baker, A. The availability of data on risk factors associated with cervical cancer. Alban. Med. J. 2014, 2, 83-91.

27. Brînzac, M.; Coci, I.; Ionaşcu, V. A quantitative study: Assessing the knowledge regarding the HPV virus and cervical cancer among Romanian young women aged between 18 and 24 years. Eur. J. Sustain. Dev. 2019, 8, 358-364. [CrossRef]

28. Guvernul României, Ministerul Sănătăţii. Comunicat de Presă (Government of Romania, Ministry of Health. Press Release). Available online: http:/ / old.ms.ro/index.php?pag=62\&id=6683\&pg=1 (accessed on 18 August 2021).

29. Politici de Sănătate. Available online: https://www.politicidesanatate.ro/vaccinarea-anti-hpv-recomandari-si-provocari/ (accessed on 18 August 2021).

30. Guvernul României, Ministerul Sănătăţii. Comunicat de Presă (Government of Romania, Ministry of Health. Press Release). Available online: http:/ / www.ms.ro/2019/11/15/vaccinarea-gratuita-antihpv/ (accessed on 18 August 2021).

31. Guvernul României, Ministerul Sănătăţii. Comunicat de Presă (Government of Romania, Ministry of Health. Press Release). Available online: http:/ /www.ms.ro/2020/01/16/seminar-de-lucru-vaccinarea-antihpv/ (accessed on 18 August 2021).

32. Crăciun, C.; Băban, A. "Who will take the blame?": Understanding the reasons why Romanian mothers decline HPV vaccination for their daughters. Vaccine 2012, 30, 6789-6793. [CrossRef]

33. Voidăzan, S.; Tarcea, M.; Morariu, S.H.; Nistor, C.A.; Uzun, C.C.; Dobreanu, M. Cunoştinţe, practice şi bariere in vaccinarea impotriva infecţiei cu Human Papilloma Virus: Abordarea unui grup de medici din România. Manag. Sanat. 2015, 19, 34-39.

34. Penţa, M.A.; Băban, A. Mass media coverage of HPV vaccination in Romania: A content analysis. Health Educ. Res. 2014, 29, 977-992. [CrossRef]

35. Grigore, M.; Teleman, S.I.; Pristavu, A.; Matei, M. Awareness and knowledge about HPV and HPV vaccine among Romanian women. J. Cancer Educ. 2018, 33, 154-159. [CrossRef]

36. Popa-Velea, O.; Diaconescu, L.V.; Ion, F.A.; Ştefancu, D.; Truţescu, C. Attachment style and perceived discrimination: Associations with depression among young lesbian, gay, and bisexual Romanian adults. J. Soc. Pers. Relat. 2019, 36, 3259-3272. [CrossRef]

37. Popa-Velea, O.; Truţescu, C.; Ionescu, E.V.; Almăşan, E.R.; Bobîrnac, G. The usefulness of the Draw-a-Person (DAP) test in the diagnosis and assessment of domestic violence. Rom. J. Leg. Med. 2016, 24, 231-235. [CrossRef]

38. Aharon, A.A.; Nehama, H.; Rishpon, S.; Baron-Epel, O. A path analysis model suggesting the association between health locus of control and compliance with childhood vaccinations. Hum. Vaccin. Immunother. 2018, 14, 1618-1625. [CrossRef]

39. Otto, C.; Bischof, G.; Rumpf, H.J.; Meyer, C.; Hapke, U.; John, U. Multiple dimensions of health locus of control in a representative population sample: Ordinal factor analysis and cross-validation of an existing three and a new four factor model. BMC Med. Res. Methodol. 2011, 11, 114. [CrossRef] [PubMed]

40. Taha, S.A.; Matheson, K.; Anisman, H. The 2009 H1N1 influenza pandemic: The role of threat, coping, and media trust on vaccination intentions in Canada. J. Health Commun. 2013, 18, 278-290. [CrossRef] [PubMed]

41. Ort, A.; Fahr, A. Using efficacy cues in persuasive health communication is more effective than employing threats-An experimental study of a vaccination intervention against Ebola. Br. J. Health Psychol. 2018, 23, 665-684. [CrossRef] [PubMed]

42. Albertsen, K.; Nielsen, M.L.; Borg, V. The Danish psychosocial work environment and symptoms of stress: The main, mediating and moderating role of sense of coherence. Work Stress 2001, 15, 241-253. [CrossRef]

43. Hood, S.C.; Beaudet, M.P.; Catlin, G. A healthy outlook. Health Rep. 1996, 7, 25-35.

44. Eriksson, M.; Lindström, B. Antonovsky's sense of coherence scale and the relation with health: A systematic review. J. Epidemiol. Community Health 2006, 60, 376-381. [CrossRef] [PubMed]

45. Fernandez, A.; Paiva, A.; Lipschitz, J.; Larson, H.; Amoyal, N.; Blaney, C.; Sillice, M.; Redding, C.; Prochaska, J. Disease prevention without relapse: Processes of change for HPV vaccination. Open J. Prev. Med. 2013, 3, 301-309. [CrossRef]

46. Fernandes, R.; Potter, B.K.; Little, J. Attitudes of undergraduate university women towards HPV vaccination: A cross-sectional study in Ottawa, Canada. BMC Women's Health 2018, 18, 134. [CrossRef] [PubMed]

47. Coles, V.A.; Patel, A.S.; Allen, F.L.; Keeping, S.T.; Carroll, S.M. The association of human papillomavirus vaccination with sexual behaviours and human papillomavirus knowledge: A systematic review. Int. J. STD AIDS 2015, 26, 777-788. [CrossRef] [PubMed]

48. Aleshire, M.E. College sorority members' knowledge and behaviors regarding human papilloma virus and cervical cancer. Nurs Clin. N. Am. 2013, 48, 215-227. [CrossRef]

49. Bendik, M.K.; Mayo, R.M.; Parker, V.G. Knowledge, perceptions, and motivations related to HPV vaccination among college women. J. Cancer Educ. 2011, 26, 459-464. [CrossRef]

50. Wong, L.P.; Sam, I.-C. Ethnically diverse female university students' knowledge and attitudes toward human papillomavirus (HPV), HPV vaccination and cervical cancer. Eur. J. Obstet. Gynecol. Reprod. Biol. 2010, 148, 90-95. [CrossRef]

51. Suryadevara, M.; Bonville, J.R.; Kline, R.M.; Magowan, C.; Domachowske, E.; Cibula, D.A.; Domachowske, J.B. Student HPV vaccine attitudes and vaccine completion by education level. Hum. Vaccin. Immunother. 2016, 12, 1491-1497. [CrossRef]

52. Popa-Velea, O.; Pamfile, D.; Popp, I. Psychosocial support and burnout at physicians attending advanced care patients: The impact of Balint training. Int. J. Behav. Med. 2014, 21, S95-S96.

53. Popa-Velea, O.; Diaconescu, L.V.; Gheorghe, I.R.; Olariu, O.; Panaitiu, I.; Cerniţanu, M.; Goma, L.; Nicov, I.; Spinei, L. Factors associated with burnout in medical academia: An exploratory analysis of Romanian and Moldavian physicians. Int. J. Env. Res. Publ. Health 2019, 16, 2382. [CrossRef] [PubMed] 
54. Wallston, B.S.; Wallston, K.A.; DeVellis, R.F. Development of Multidimensional Health Locus of Control (MHLC) Scale. Health Educ. Monogr. 1978, 6, 160-170. [CrossRef]

55. Ross, T.P.; Thomson Ross, L.; Short, S.D.; Cataldo, S. The Multidimensional Health Locus of Control Scale: Psychometric properties and form equivalence. Psychol. Rep. 2015, 116, 889-913. [CrossRef]

56. Luszcynska, A.; Schwarzer, R. Multidimensional health locus of control: Comments on the construct and its measurement. J. Health Psychol. 2005, 10, 633-642. [CrossRef]

57. Carver, C.S. You want to measure coping but your protocol's too long: Consider the Brief COPE. Int. J. Behav. Med. 1997, 4, 92-100. [CrossRef] [PubMed]

58. Crassovan, D.I.; Sava, F.A. Translation, adaptation and validation on Romanian population of COPE Questionnaire for coping mechanisms analysis. Cogn. Brain Behav. 2013, 17, 61-76.

59. Antonovsky, A. Unraveling the Mystery of Health. How People Manage Stress and Stay Well; Jossey-Bass Publishers: San Francisco, CA, USA, 1987; pp. 63-88.

60. Antonovsky, A. The life cycle, mental health and the sense of coherence. Isr. J. Psychiatry Relat. Sci. 1985, 22, 273-280. [PubMed]

61. Antonovsky, A. The structure and properties of the Sense of Coherence Scale. Soc. Sci. Med. 1993, 36, 725-733. [CrossRef]

62. Waller, J.; Ostini, R.; Marlow, L.A.V.; McCaffery, K.; Zimet, G. Validation of a measure of knowledge about human papillomavirus (HPV) using item response theory and classical test theory. Prev. Med. 2013, 56, 35-40. [CrossRef] [PubMed]

63. Patel, D.A.; Grunzweig, K.A.; Zochowski, M.K.; Dempsey, A.F.; Carlos, R.C.; Dalton, V.K. Human papillomavirus vaccine stages of change among male and female university students: Ready or not? J Amer Coll Health 2013, 61, 336-346. [CrossRef] [PubMed]

64. Prochaska, J.O.; Velicer, W.F. The transtheoretical model of health behavior change. Am. J. Health Promot. 1997, 12, 38-48. [CrossRef]

65. Stein, M.M.; Sabo, M.; Caverly, J. Relationship between stages of change and HPV vaccine attitudes and beliefs in baccalaureate nursing students. Honors Res. Proj. 2015, 104.

66. Colomer-Pérez, N.; Paredes-Carbonell, J.J.; Sarabia-Cobo, C.; Gea-Caballero, V. Sense of coherence, academic performance and professional vocation in Certified Nursing Assistant students. Nurse Educ. Today. 2019, 79, 8-13. [CrossRef]

67. Salamonson, Y.; Ramjan, L.M.; van den Nieuwenhuizen, S.; Metcalfe, L.; Chang, S.; Everett, B. Sense of coherence, self-regulated learning and academic performance in first year nursing students: A cluster analysis approach. Nurse Educ. Pract. 2016, 17, 208-213. [CrossRef] [PubMed]

68. Chu, J.J.; Khan, M.H.; Jahn, H.J.; Kraemer, A. Sense of coherence and associated factors among university students in China: Cross-sectional evidence. BMC Public Health 2016, 16, 336. [CrossRef]

69. Fares, J.; Al Tabosh, H.; Saadeddin, Z.; El Mouhayyar, C.; Aridi, H. Stress, burnout and coping strategies in preclinical medical students. N. Am. J. Med. Sci. 2016, 8, 75-81. [CrossRef] [PubMed]

70. Sherman, K.A.; Kilby, C.J.; Moore, D.M.; Laura-Kate Shaw, L.K. The importance of coherently understanding cervical cancer vaccination: Factors associated with young Australian women's uptake of the HPV vaccine. Health Psychol. Behav. Med. 2017, 5, 358-371. [CrossRef]

71. Jung, S.; Kneer, J.; Krüger, T.H.C. Mental health, sense of coherence, and interpersonal violence during the COVID-19 pandemic lockdown in Germany. J. Clin. Med. 2020, 9, 3708. [CrossRef] [PubMed]

72. Danioni, F.; Sorgente, A.; Barni, D.; Canzi, E.; Ferrari, L.; Ranieri, S.; Iafrate, R.; Regalia, C.; Rosnati, R.; Lanz, M. Sense of coherence and COVID-19: A longitudinal study. J. Psychol. 2021, 1-21. [CrossRef] [PubMed]

73. Helmer, S.M.; Krämer, A.; Mikolajczyk, R.T. Health-related locus of control and health behaviour among university students in North Rhine Westphalia, Germany. BMC Res. Notes 2012, 5, 703. [CrossRef] [PubMed]

74. Kurt, A.S. The relationship between healthy lifestyle behaviors and health locus of control among Nursing and Midwifery students. Am. J. Nurs. Res. 2015, 3, 36-40. [CrossRef]

75. Slopiecka, A.; Chrapek, M. Relationship between health related locus of control and health behaviour among university students. Sleep Med. Dis. Int. J. 2019, 3, 10-15. [CrossRef]

76. Çepni, S.A.; Kitiș, Y. Relationship between healthy lifestyle behaviors and health locus of control and health-specific self-efficacy in university students. Jpn. J. Nurs. Sci. 2017, 14, 231-239. [CrossRef]

77. Saei Ghare Naz, M.; Darooneh, T.; Rashidi Fakari, F.; Kholosi Badr, F.; Hajizadeh, F.; Ozgoli, G. The relationship between health locus of control and Iranian women's beliefs toward pap smear screening. Int. J. Community Based Nurs. Midwifery 2019, 7, 43-51. [CrossRef]

78. Bąk, B.; Sikorski, M.; Wrześniewska, M. Health locus of control of women vaccinated against HPV. Studia Med. 2012, 27, 15-22.

79. Vanderpool, R.C.; Dressler, E.V.; Stradtman, L.R.; Crosby, R.A. Fatalistic beliefs and completion of the HPV vaccination series among a sample of young Appalachian Kentucky women. J. Rural Health. 2015, 31, 99-205. [CrossRef]

80. Kang, H.S.; Moneyham, L. Attitudes toward and intention to receive the human papilloma virus (HPV) vaccination and intention to use condoms among female Korean college students. Vaccine 2010, 28, 811-816. [CrossRef] [PubMed]

81. Gu, C.N. Human papillomavirus vaccine acceptability among female undergraduate students in China: The role of knowledge and psychosocial factors. J. Clin. Nurs. 2015, 24, 2765-2778. [CrossRef] [PubMed]

82. Navalpakam, A.D. Behavioral perceptions of Oakland University female college students towards human papillomavirus vaccination. PLoS ONE 2016, 11, e0155955. [CrossRef] 
83. Jeudin, P.; Liveright, E.; Del Carmen, M.G.; Perkins, R.B. Race, ethnicity, and income factors impacting human papillomavirus vaccination rates. Clin. Ther. 2014, 36, 24-37. [CrossRef] [PubMed]

84. Niccolai, L.M.; Mehta, N.R.; Hadler, J.L. Racial/Ethnic and poverty disparities in human papillomavirus vaccination completion. Am. J. Prev. Med. 2011, 41, 428-433. [CrossRef] [PubMed]

85. Geshnizjani, A.; Jozkowski, K.N.; Middlestadt, S.E. Factors influencing the intention of getting the HPV vaccine among college women: An application of the Reasoned Action approach. Calif. J. Health Promot. 2013, 11, 1-11. [CrossRef] 